UJBM, Vol.2, No. 1, January - June 2003, pp 24-37

ISSN 0975-3311

https:/ / doi.org/ 10.12725/ ujbm.2.3

\title{
GLOBALIZATION AND THE POST-MODERN TURN
}

\author{
James David*
}

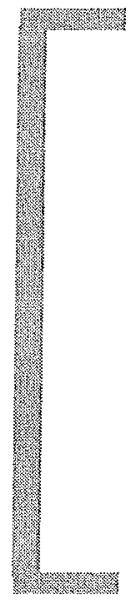

\section{Abstract}

We need a critical theory of globalization that is necessarily transdisciplinary and that, which does not buy into ideological valorizations and affirms difference, resistance, and democratic self-determination against forms of global domination and subordination. A wide range of theorists has argued that the proliferation of differences and the shift from the level of globalization to focus on the local, the specific, the particular, the heterogeneous, and the micro level of everyday experience. Several theories are associated with post-structuralism, postmodernism, feminism, and multiculturalism and focus on difference, 'otherness', marginality, the personal, the particular, and the concrete over more general theory and politics that aim of more global or universal conditions.

There is no doubt that globalization is the buzzword of the decade. Journalists, politicians, business executives, academics, and others are using the word to signify that something profound is happening, that the world is changing that a New

*Management Consultant with John Watson Group. E-mail: jimdavid@vsnl.com 
World of economic, political, and cultural order is emerging. Yet the term is used in so many different contexts, by so many different people, for so many different purposes, that it is difficult to ascertain what is at stake in the globalization problematic, what function the term serves, and what effects it has for contemporary theory and politics.

A wide and diverse range of social theorists are arguing that today's world is organized by increasing globalization through:

- Strengthening the dominance of a world capitalist economic system;

- Supplanting the primacy of the nation state by transnational corporations and organizations; and

- Eroding local cultures and traditions through a global culture.

Marxists, advocates of world's systems theory, functionalists, Weberians, and many other contemporary theorists are converging on the position that globalization is a distinguishing trend of the present moment.

The purposes for which the concept 'Globalization' is used and the evaluations of the processes described by the concept vary wildly. For some:

- Globalization entails the Westernisation of the World;

- Globalization involves a cover for the ascendancy of capitalism;

- Globalization causes increasing homogeneity;

- Globalization produces diversity and heterogeneity through increased hybridization.

For business: Globalization is a strategy for increasing corporate profits and power. For government: Globalization is often deployed to promote an increase in state power. For non-government social organizations: Globalization is lever to produce positive social goods like environmental action, democratization, or humanization.

Globalization is caught up in some of the central debates and conflicts of the present age. During the past decades, the world has been undergoing the most significant period of technological innovation and global restructuring since the first decades of the twentieth century. Part of the "great transformation" [1] to a new stage of techno-capitalism has involved a fundamental restructuring and reorganization of the world economy, polity, and culture for which the term globalization serves as a codeword. 


\section{Theorizing Globalization}

Globalization is bound up with highly ideological discourses of the present age. It is being used by some to represent:

- An entirely positive process of economic and social progress,

- Technological innovation, more diverse products and services, a profusion of information and growing cultural freedom, and

- Higher standard of living.

Pro-globalization boosters include champions of the market economy since the triumph of Thatcher-Reaganism in the 1980s.

For its critics, however, globalization is bringing about:

- Devastating destruction of local traditions,

- Continued subordination of poorer nations and regions by richer ones,

- Environmental destruction, and

- Homogenization of culfure and everyday life.

These critics include Marxists, liberals, and 'multi-culturalists' who stress the threat to national sovereignty, local traditions, participatory democracy through global forces, environmentalists who fear the destructive ecological effects of unchecked globalization, and conservatives who see globalization as a threat to national and local cultures and the sanctity of tradition.

The term globalization is thus a theoretical construct that itself is contested and opens for various meanings and inflections. It can be described positively or negatively, to describe highly complex and multidimensional processes in the economy, polity, culture, and everyday life. A critical theory of globalization attempts to specify the interconnections and interdependencies between different levels such as the economic, political, cultural and psychological, as well as between different flows of products, ideas and information, people, and technology.

The highly complex articulations of the discourse of globalization are rendered more complicated because globalization is not only a replacement term for imperialism and modernization, but it is caught up in the modernity and/or postmodernity debates as well. For some, globalization thus constitutes a continuation of the problematic countenance of modernization and modernity, while for others, it signifies something new and different and is bound up with the postmodern turn, or an altogether novel and as yet un-theorized global condition. 
For some theorists, globalization is seen as a process of standardization in which a globalized media and consumer culture circulates the globe creating sameness and homogeneity everywhere, thus bringing to light the bland and boring universality and 'massification'. Post-modernists champion, by contrast, the local, diversity, difference, and heterogeneity. They sometimes claim that globalization itself produces 'hybridity' and multiplicity, arguing that global culture makes possible unique appropriations and developments all over the world with new forms of hybrid syntheses of the global and the local, thus proliferating difference and heterogeneity. Post-modernists also argue that every local context involves its own appropriation and reworking of global products and signifiers, thus producing more variety and diversity.

\section{Globalization: Economy/State/Culture}

The term "globalization" is thus often used as a code word that stands for a tremendous diversity of issues and problems and that serves as a front for a variety of theoretical and political positions. In view of the different concepts and functions of globalization discourse, it is important to note that the concept is a theoretical construct that varies according to the assumptions and commitments of the theory in question. Seeing the term globalization as a construct helps rob it of its force of nature, as a sign of an inexorable triumph of market forces and the hegemony of capital, or, as the extreme right fears, of a rapidly encroaching world government. While the term can both describe and legitimate and normalize capitalist transnationalism, and transnational government institutions, a critical theory of globalization does not buy into ideological valorizations and affirms difference, resistance, and democratic self-determination against forms of global domination and subordination.

A critical theory of globalization is necessarily transdisciplinary and describes the ways that global economic, political, and cultural forces are rapidly creating a New World market, new transnational political organizations, and a new global culture. True it is that the expansion of the capitalist world market into areas previously off limits to it such as the communist sphere or developing countries. They attempted to pursue their own independent line of development. The arrival of the world market is accompanied by the decline of the nation-stale and its power to regulate and control the flow of goods, people, information, and various cultural forms. There have been national liberation movements, disrupted colonial empires of power and created a "Third Way" between the capitalist and communist blocs, especially in the period after World War Two, marked by the success of a large 
number of anti-imperialist revolutions. But as we approach the end of the fwentieth century, it would seem that neither de-colonization nor the end of the Cold War has loosened the hold of transnational systems of domination.

In addition to the development of a new global market economy and shifting system of nation-states, the rise of global culture is an especially salient feature of contemporary globalization. Accompanying the dramatic expansion of capitalism and new transnational political organizations a new global culture is emerging as a result of computer and communications technology. It is a consumer society with its panorama of goods and services, transnational forms of architecture and design, and a wide range of products and cultural forms that are traversing national boundaries and becoming part of a New World culture. Global culture includes the proliferation of media technologies that veritably create Marshall McLuhan's dream of a global village, in which people all over the world watch political spectacles like the Gulf War, major sports events, entertainment programs and advertisements that relentlessly promote capitalist modernization. At the same time, more and more people are entering into global computer networks that instantaneously circulate ideas, information, and images throughout the world, overcoming boundaries of space and time.

Global culture involves promoting life-style, consumption, products, and identities. Culture has been precisely the particularizing, localizing force that distinguished societies and people from each other. Culture provided forms of local identities, practices, and modes of everyday life that could serve as a bastion against the invasion of ideas, identities, and forms of life extraneous to the specific local region in question. Indeed, culture is an especially complex and contested terrain today as global culfures permeate local ones and new configurations emerge that synthesize both poles, providing contradictory forces of colonization and resistance, global homogenization and new local hybrid forms and identities.

Yet, the very concept of globalization has long been a contested terrain described in conflicting positive and negative normative discourses. It is perhaps the early theorists and critics of capitalism who first engaged the phenomenon of the globalization of the capitalist system. Not surprisingly, the defenders of capitalism, such as Adam Smith, saw the process positively, whereas Karl Marx and Friedrich Engels had more critical perceptions. Producing one of the first major discourses of globalization, Smith saw the European "discoveries" of the Americas and the passage to the East Indies as creating a new world market with highly significant consequences.

Smith envisaged the emergence of a world market system as one of the most important features of modernity that would eventually benefit the entire world. Although 
perceiving the injustices of unequal relations of power and force, Smith generally appraised the globalization of the world market as "beneficial." With characteristic honesty, he cited the "misfortunes" of the process of colonization, but optimistically believed that the injustices of the process might be overcome. In "The Communist Manifesto," Marx and Engels followed Smith in seeing the importance of the globalization of the capitalist market, although, of course, they differed in their evaluation of it. Closely following the optic of Smith, they claimed:

Both the classical liberalism of Smith and classical Marxism thus see capitalism as a global economic system characterized by a world market and the imposition of similar relations of production, commodities, and culture on areas throughout the world. It would be creating a new modern world-system as the capitalist market penetrates the four corners of the earth. For both classical liberalism and Marism, the bourgeoisie constantly revolutionized the instruments of production and the world market generated immense forces of commerce, navigation and discovery, communications, and industry, creating a New World of abundance, diversity, and prosperity.

Curiously, the Marxian theory shared the illusions of many market liberals that the development of a world-system of free trade would eliminate nationalism and the nation-state, with both downplaying their importance, in a New World economic order - be it capitalist or communist. Both Smith and Marx present colonization and the globalization of the market society as inevitable and as the basis of material progress. Both recognize the injustices of the process for the victims of colonization and the use of violence and superior force to subjugate non-Western culture. However, both are sanguine about the process and draw distinctions between "barbarian nations" and civilizations that ultimately present globalization as a "civilizing process" - this would indeed emerge as one of the dominant ideologies of imperialism.

For several centuries, globalization proceeded on an increasingly rising curve, bringing more and more areas of the world into the world market-system. World War One and its aftermath produced a slowing down of this process, however, first, enmeshing much of the Western world in a highly destructive war, followed by a period of economic boom and bust, protectionism, growing nationalism, and the failure of internationalist economic and political policy. World War Two once again engulfed much of the world in an even more destructive and global war, though already during the war itself events occurred that would shape the post-War world economic order. At the Bretton Woods conference in 1944, monetary arrangements were undertaken which would help produce a globalized world order. At the end of this meeting, the World Bank and I.M.F. were founded. With the end 
of the war, world trade exploded with a vengeance. National trade barriers were systematically dismantled and eroded, global economic forces penetrated local economies and a global consumer and media culture traversed the globe. The results have been auspicious.

As we look back fitty years later, we can see that economic growth has expanded fivefold, international trade has expanded by roughly twelve times and foreign direct investment has been expanding at two of three times the rate of trade expansion. Yet the results of these developments have been highly uneven. While economic elite and corporations have benefited tremendously the rewards have been unequally distributed. Gaps between rich and poor, the 'haves' and the 'have-nots', the overdeveloped and underdeveloped regions, have grown exponentially. The wealthier nations continue to exploit the people, resources, and land of the poorer nations, often leaving environmental degradation behind. The debt crisis in which the poorer countries owe the richer ones astronomical sums has increased dramatically since the 1970s. There are more poor people in the world today than ever before; violence on the local, national, and global scale has erupted throughout this century of unmitigated disaster and horror; the planet's ecosystem is under siege and the "fate of the earth" lies in immediate jeopardy. For much of the world, life is still "nasty, brutish, and short," and prosperity, health, education, and welfare remain distant dreams for much of the overpopulation of the besieged earth.

\section{Resisting Globalization}

The concept of globalization can be dis-empowering leading to cynicism and hopelessness. This arises out of an underlying belief that inexorable market forces cannot be regulated and controlled by the state, or that the economy cannot be shaped and directed by the people, thus undermining democracy and countervailing powers to the hegemony of capital. A critical theory of globalization, however, recognizes the reality of globalization, its power and effects, but also seeks forces of resistance and struggle that attempt to counter the most destructive aspects of global forces, or which inflects globalization for democratic and locally empowering ends. The present conjuncture, I would suggest, is marked by a conflict between growing centralization and organization of power and wealth in the hands of the few contrasted to opposing processes exhibiting a fragmentation of power that is more plural, multiple, and open to confestation than previously. As the following analysis will suggest, both tendencies are observable and it is up to individuals and groups to find openings for contestation and struggle. 
Global economic change often has tremendous local impact. Whole regions are devastated with the shutting down of industrial production, moved to regions with lower wages and less government regulation. Such "de-industrialization" has created vast "rust belts" or previously prosperous industrial regions, as in the case of Flint, Michigan, which suffered major economic decline with the closing of General Motors automobile plants. It is an episode documented in Michael Moore's film Roger and Me. Automation, computers, and new technologies have eliminated entire categories of labor while corporate reorganization has abolished segments of management, producing vast unemployment. Corporations like Nike move from country to country in search of lower labor costs and more docile work forces. More than ever, the world economy is bound together so that hurricanes in Japan or financial irregularities in Britain influence the entire world.

Consequently, globalization involves new connections and the integration of economies and cultures into a world system, overcoming previous divisions and distances. Especially during the period of the Cold War arising after World War II, the system of modern nation-states divided into two camps - capitalist and socialist producing a shifting series of alliances and conflicts influencing countries from Vietnam to Nicaragua. During this period, nations either pursued the capitalist or socialist model of development - or in the case of some so-called Third World nations attempted to forge their own path of development. As the term suggests, the Third World nations created by de-colonization were often considered to be less important to global affairs than the conflict between the world superpowers. The binaristic Cold War model provided a convenient rubric for economic, political and cultural intervention into Third World affairs, dividing the world into a global field of conflict between the two superpowers with much of the planet caught in the middle.

But with the collapse of the communist system, this period of history came to an end and during the 1990s the capitalist market model of globalizaiton has become dominant and practically uncontested. The analogue of such economic globalization is said to be the triumph of democracy throughout the world with its discourse and institutions of a pluralistic system of checks and balances, parties, elections, and human rights (Fukuyama 1992). For some decades, indeed, democracy has been interpreted as the necessary accompaniment and/or condition of capitalism, while a tradition of critical theory documents the tensions and conflicts between democracy and capitalism.

And yet the decline of the power of the nation-state produces a new geopolitical matrix in which transnational organizations, corporations, and forces challenge national and local sites of power and influence. In the wake of political developments such as decolonization, the end of the Cold War, the formation of new trade 
agreements and political unions, and the rise of global transnational capitalism, national borders have shiffed, resulting in the increased power of transnational institutions. Accompanying such momentous political changes are the increasing prominence of world trade, financial speculations and investment, and global cultural forces that operate outside the confines of the nation-state as a discrete entity.

And yet new conflicts also have emerged exhibiting a surge of nationalism and fundamentalism and clashes of cultures. It is curious how classical liberalism, Marxism, and modernization theory downplayed the importance of culture and local forms of social association, positing the inexorable advance of the modern economy, technology, and politics which would supposedly level out and homogenize all societies and culture, producing a world global culture. Both capitalism with its world market and communism with its international socio-economic system and political culture were supposed to erode cultural differences, regional particularities, nationalism, and traditionalism. Thus, both classical liberalism and Marxism promoted or predicted globalization as the fate of the world. For capitalist ideologues, the market was going to produce a global world culture. For Marism the proletariat was going to produce commnunism that would eliminate nationalism and create a communist international without exploitation or war. Both saw the significance of national borders being eliminated and both seriously underestimated the endurance of nationalism and the nation-state.

Missing from both Marxist and liberal models has been an understanding of how race, ethnicity, and nationalist sentiment might intersect with class to produce local, political struggles with complex causes. Indeed, from the late 1980s to the present, there has been a resurgence of nationalism, traditionalism, and religious fundamentalism alongside trends toward growing globalization. The explosion of regional, culfural, and religious differences in the former Soviet Union and Yugoslavia - as well as explosive tribal conflicts in Africa and elsewhere - suggests that globalization and homogenization were not as deep as its proponents hoped and critics feared. Culture has thus become a new source of conflict and an important dimension of struggle between the global and the local. National cultures have produced confrontations between Serbs, Muslims, and Croats, Armenians and Azarbijanis, Mohawk First Nation peoples and Quebecois, and in South Africa struggles between the Umkatha tribe and the African National Congress. Thus, both culture and nationalism turned out to be more enduring, deeper, and fundamental than expected and clashes between the global and local and various national cultures with each other continue in a supposedly globalized world.

It is also in the realm of culture that globalization is most visible and apparent. Global media and information systems and a world capitalist consumer culture 
circulate products, images, and ideas throughout the world. Events such as the Gulf War, social trends and fashions, and cultural phenomena such as Madonna, rap music, and popular Hollywood films are distributed through global cultural distribution networks and constitute a "global popular". This global culture, however, operates precisely through the multiplication of different products, services, and spectacles, targeted at specific audiences. Consumer and media industries are becoming more differentiated and are segmenting their customers and audiences into more categories. In many cases, this involves the simulation of minor differences of fastion and style as significant, but it also involves a proliferation of a more highly differentiated culture and society in terms of an ever-expanding variety and diversity of cultural artifacts, products, and services.

However, there has also been a significant eruption of subcultures of resistance that has attempted to preserve specific forms of culture and society against globalization and homogenization. Most dramatically, peasant movements in Mexico, guerrilla movements in Peru, labor unions in France, students in Britain and the United States, environmentalists throughout the world, and a variety of other groups and movements have resisted capitalist globalization and attacks on previous rights and benefits. Seven dozen people's organizations from around the world have protested World Trade Organization policies and a backlash against globalization is visible everywhere. Politicians who once championed trade agreements like GATT and NAFTA are now quiet about these arrangements and at the 1996 annual Davos World Economic Forum its founder and managing director published a warning entitled: "Start Taking the Backlash Againsi Globalization Seriously" (New York Times, February 7, 1996: A15).

On the terrain of everyday life, new youth subcultures of resistance are visible throughout the world, as are alternative subcultures of women, gays and lesbians, blacks and ethnic minorities, and other groups that have resisted incorporation into the hegemonic mainstream culture. British cultural studies has accordingly explored both mainstream hegemonic cultures and oppositional subcultures since the 1970s. It has focused on articulations of class, race, gender, sexual preference, ethnicity, region, and nation in its explorations of concrete cultural configurations and phenomena. More recently, cultural studies has also taken on a global focus, analyzing how transnational forces intervene in concrete situations and how cultural mediations can inflect the influence of such global configurations.

Indeed, a wide range of theorists has argued that the proliferation of difference and the shift to more local discourses and practices define the contemporary scene. They also reason that the theory and politics should shift from the level of globalization to focus on the local, the specific, the particular, the heterogeneous, and the micro 
level of everyday experience. A wide range of theories associated with poststructuralism, post-modernism, feminism, and multiculturalism focuses on difference, 'otherness', marginality, the personal, the particular, and the concrete over more general theory and politics that aim at more global or universal conditions.

Our challenge to think through the relationships between the global and the local by observing how global forces influence and even structure ever more local situations and ever more strikingly. One should also see how local forces and situations mediate the global, inflecting global forces to diverse ends and conditions, and producing unique configurations of the local and the global as the matrix for thought and action in the contemporary world.

Indeed, in many various fields and disciplines, theorists are beginning to consider how global, systemic, and macro-structures interact with local, particular, and micro-conditions and structures. Such dialectical optics attempt to theorize the intersection of the global and the local, how they interact and mediate each other, and the new constellations being produced by current interactions between these forces. In this way, one overcomes the partiality and one-sidedness of un-dialectical theories that fail to perceive the ways that the global and the local inferact so as to produce new social and culural configurations.

Analogous to the question of conceptualizing the interactions of the global and the local on the level of theory, debates have emerged over the proper locus and focus of politics today. So theorists argue that global and national problems require macro-structural solutions, while others argue that the proper sphere of the political is the local and the personal, and not the global or national. Post-modern theories of power, for instance, have stressed how power inhabits local, specific, and micro realms, ignored by modern theories that located powers in centers such as the economy, the state, or patriarchy. Post-modern politics urges local and specific actions to intervene in discursive sites of power ranging from the bedroom to the classroom, from prisons to mental institutions.

Rethinking politics in the present conflicted and complex configurations of both novel and established relations of power and domination thus requires thinking through the complex ways in which the global and the local are interconnected. Theorizing the configurations of the global and the local also requires developing new multidimensional strategies ranging from the macro to the micro, the national to the local, in order to intervene in a wide range of contemporary and emerging problems and struggles. Globalization yields the possibility of new concepts of global citizenship that will make us responsible and participatory in the problems and challenges of the coming global village. To the slogan, "Think globally, act locally," we may thus add the slogan, "Think locally, act globally." From this 
perspective, problems related to global environment, global information superhighway, global forums for discussing and resolving war and peace, global poverty and inequality, and overcoming divisions between the haves and the havenots may produce new conceptions of global citizenship and new challenges for global intellectuals and activists.

Globalization is thus necessarily complex and challenging to both our theories and politics. But most people these days, including theorists who should know better, operate with binary concepts of the global and the local, the modern or the post-modern, and promote one or the other side of the equation as the solution to the world's problems. For globalists, globalization is the solution and underdevelopment, backwardness, and provincialism is the problem. For localists, globalization is the problem and localization is the solution. But, less simplistically, it is the mix that matters and whether global or local solutions are most appropriate depends on the conditions in the specific context that one is addressing. In a complex, globalized world, there is no easy formula to solve the intransigent problems of the present era. Yet, there are so many problems on so many levels, that it should not be difficult for people of imagination and good will to find opportunities for intervention in a variety of areas.

\section{Globalization and the Post-modern Turn: Concluding Remarks}

Acting in the present age involves understanding the matrix of global and local forces, of forces of domination and resistance and of a condition of rapid change and a "great transformation" brought about by the global restructuring of capital and multidimensional effects of new technologies. The future is up for grabs, as are characterization of where we now are, where we are going, and what concepts and perspectives best characterize our present dilemma. We are living in a period between the modern and something new for which the term "post-modern" stands as a marker. One could, of course, describe the tensions between global and the local, the modern and the post-modern, and the old and the new, as a process of post-modernization, of increasing complexity, fragmentation and uncertainty. Although a post-modern turn is visible, continuities with the modern are so striking that it is a mistake to posit a post-modern rupture and exaggerate discontinuities.

This is certainly the case with globalization for clearly the process has been going on for centuries and, as the earlier discussion of Adam Smith and Marx suggested, globalization itself is bound up with capitalist modernity and the expansion of the capitalist system. Yet, there are also striking novelties in the present age. The rapidity 
of globalization with its space-time compression, its simultaneous forms of mass communication, its instantaneous financial transactions, and an increasingly integrated world market is surely a novelty. New technologies are changing the nature of work and creating new forms of leisure, including the hyper-reality of cyberspace, new virtual realities, and new modes of information and entertainment. Capital is producing a new fechno-culture, a new form of the entertainment and information society, and everything from education to work to politics and everyday life is dramatically changing.

These novelties are sufficiently great at present to postulate a complete post-modern rupture. Capitalist relations of production still structure most social orders and the hegemony of capital is still the structuring force of most dimensions of social life. Dramatic change and innovation have been part of modernity for centuries, as has technological development and expansion. Yet these phenomena, bound up with globalization in its current phase, have created enough novelties to require a rethinking of social theory and politics in the current situation as a response to new developments in society and culture.

In sum and to conclude: historical epochs do not rise and fall in neat patterns or at precise chronological moments. Perhaps our current situation is parallel in some ways to the Renaissance, which constituted a long period of transition between the end of pre-modern societies and the emergence of modern ones. Such periods are characterized by unevenly developing multiple levels of change, and the birth pangs associated with the eruption of a new era. In fact, change between one era and another is always protracted, contradictory, and usually painful. But the vivid sense of transition, requires that one grasp the connections with the past as well as the novelties of the present and future. Thus, it is important to capture both the continuities and discontinuities of the post-modern with the modern, in order to make sense of our current predicament.

Living in a border land between the modern and post-modern creates tension, insecurity, confusion, and even panic, as well as excitement and exhilaration, thus producing a cultural and social environment of shifting moods and an open but troubling future. The concept of a postmodern turn is aware of the risks and dangers in the current social constellation, as well as the hope of new possibilities and excitement. The post-modern turn is thus deeply implicated in the moods and experiences of the present and is an important component of our contemporary situation. The very ubiquity of the discourse of the "post-modern," its constant proliferation, its refusal to fade away and its seeming longevity suggest that it is addressing current concerns in a useful way. It illuminates salient present-day realities; it resonates with shared experience, and that it is simply an ingrained part 
of the current critical lexicon that one has to come to terms with, one way or another.

\section{End Notes}

1. Polyani (1957: 189) on how market liberals failed to see the importance of the nation state and nationalism, an oversight shared by Marx. Today, it is mostly transnationalist neo-liberals who continue to downplay the importance of the nation and who champion transnational structures, though this was also long part of the ideology of international communism.

2. On de-industrialization, see Bluestone and Harrison 1982 and on post-Fordism, see Harvey 1989. v. Fukuyama's "end of history" thesis more accurately describes the end of a peculiar period of history; see Fukuyama 1992 and the critique in Derrida 1994. 